\section{In Vitro Antigen-induced Antibody Responses to Hepatitis B Surface Antigen in Man Kinetic and Cellular Requirements}

Thomas R. Cupps, John L. Gerin, Robert H. Purcell, Paul K. Goldsmith, and Anthony S. Fauci Laboratory of Immunoregulation and Laboratory of Infectious Diseases, National Institute of Allergy and Infectious Diseases, Laboratory of Biochemistry and Metabolism, National Institute of Arthritis, Diabetes, and Digestive and Kidney Diseases, National Institutes of Health, Bethesda, Maryland 20205, and Division of Molecular Virology and Immunology, Georgetown Medical Center, Rockville, Maryland 20850 bstract. In this report we define the parameters of the human immune response after immunization with hepatitis B vaccine. 2 wk after booster immunization, there is significant spontaneous secretion of antibody to hepatitis B surface antigen (anti-HBs IgG), which is not further augmented by stimulation with antigen or pokeweed mitogen (PWM). By 4 wk there is little spontaneous secretion of specific antibody, and low doses of antigen or PWM produce significant increases in the amount of anti-HBs IgG produced. By 8 wk the peripheral blood mononuclear cells are refractory to stimulation by antigen, but anti-HBs IgG is produced in response to PWM. 0.5 yr or more after the last immunization, some individuals will manifest an antigeninduced specific antibody response. This induction of anti-HBs IgG by hepatitis B surface antigen (HBsAg) is monocyte- and $\mathrm{T}$ cell-dependent. Note that there is a dichotomy in the $\mathrm{T}$ cell response to $\mathrm{HBsAg}$. The specific antibody response is clearly $T$ cell dependent, but no in vitro $T$ cell proliferative response to HBsAG could be demonstrated in the immunized individuals. Although the precise reason for the absent proliferative response to $\mathrm{HBsAg}$ despite well-established humoral immunity has not been determined, there was no evidence to suggest nonspecific suppression by $\mathrm{HBsAg}$ or the presence

Dr. Cupps is currently with the Division of Rheumatology, Immunology, and Allergy, Department of Medicine, Georgetown University Medical Center.

Received for publication 22 November 1983 and in revised form 24 May 1984.

The Journal of Clinical Investigation, Inc.

Volume 74, October 1984, 1204-1213 of an adherent suppressor cell population. The ability to evaluate antigen-induced, antigen-specific responses to $\mathrm{HBsAg}$ will be useful in defining the unique interaction between the human immune response and this clinically important viral agent.

\section{Introduction}

The human immune response to hepatitis B virus infection is variable. Although the vast majority of people infected with hepatitis B virus respond by clearing the hepatitis B surface antigen (HBsAg) ${ }^{1}$ and developing antibody to $\mathrm{HBsAg}$ (antiHBs IgG), a small percentage (5-10\%) will not resolve the infection; viral synthesis persists, and the individual becomes a chronic carrier of HBsAg (1). Several clinical syndromes are associated with the absent or incomplete immune response to HBsAg. Aberrant immune responses to HBsAg that result in immune complex formation and subsequent tissue deposition have been causally implicated in some cases of cryoglobulinemia (2), glomerulonephritis $(3,4)$, and systemic necrotizing vasculitis $(5,6)$. The association of the chronic $\mathrm{HBsAg}$ carrier state and chronic state and chronic hepatitis has also been emphasized $(7,8)$ and extensively investigated (reviewed, 9 and 10). The ability to evaluate the human immune response to $\mathrm{HBsAg}$ could provide insights into a number of clinical syndromes associated with an aberrant immune response to this agent.

Although a great deal can and has been learned about normal and aberrant regulation of specific antibody production

\footnotetext{
1. Abbreviations used in this paper: anti-HBs IgG, antibody to hepatitis B surface antigen; ELISA, enzyme-linked immunosorbent assay; FCS, fetal calf serum; HBsAg, hepatitis B surface antigen; $\mathrm{KLH}$, keyhole limpet hemocyanin; MLR, mixed leukocyte reaction; PBMC, peripheral blood mononuclear cell; PWM, pokeweed mitogen; TCD, T cell depleted; TCE, T cell enriched; TT, tetanus toxoid.
} 
after stimulation by polyclonal B cell activators $(11,12)$, including anti-HBs IgG production after activation with pokeweed mitogen (PWM) (13), the dichotomy in specific antibody production after stimulation with polyclonal B cell activator versus that after stimulation with antigen has been emphasized $(14,15)$. In vitro antigen-induced specific antibody production has been described in response to both nonviral (14-16) and viral antigens (17-19), but not in response to HBsAg. The recent development and successful use of HBsAg vaccine (2022) has provided a model for evaluating more precisely the human immune response to $\mathrm{HBsAg}$. In this report we demonstrate in vitro antigen-induced specific antibody responses to $\mathrm{HBsAg}$ in man after immunization with $\mathrm{HBs} A g$ vaccine. The response is critically dependent upon the postimmunization kinetics of the circulating peripheral blood lymphocyte repertoire. The antigen-induced response also depends upon the presence of monocytes and $T$ cells in culture. Despite the $T$ cell dependence of the specific antibody response, no proliferative response to $\mathrm{HBsAg}$ could be demonstrated.

\section{Methods}

Immunization. Normal subjects, aged 21-37 yr, received 0.5-ml (20 $\mu \mathrm{g}$ of antigen as protein) intramuscular injections of the $\mathrm{HBs} \mathrm{Ag}$ vaccine (lot A-9; National Institutes of Health, Bethesda, MD) (21). 1 and 6 mo after the initial immunization, the booster immunizations were administered. The immunizations were carried out under peer-reviewed National Institutes of Health protocols. Of the 25 normal subjects immunized, 24 had evidence of a positive serologic response, as determined by Ausab (Abbott Laboratories, Diagnostic Div., North Chicago, IL) after completion of the three shot series. The 14 normal subjects who had evidence of a positive serologic response after the first immunization were selected for study after the second and/or third immunization.

HBsAg. The HBsAg (serotype adw) was prepared from the plasma of a single donor. Highly purified 22-nm particles were prepared by sequential density gradient separation using zonal centrifugation procedures as previously described (23). The $\mathrm{HBsAg}$, at a concentration of $438 \mu \mathrm{g} / \mathrm{ml}$ protein as determined by the method of Lowry (24), was stored at $-70^{\circ} \mathrm{C}$ until needed and then kept at $4^{\circ} \mathrm{C}$ while being used.

Cell separations. Peripheral blood mononuclear cells (PBMCs) were obtained from Hypaque-Ficoll gradients in the standard fashion (25). $T$ cell-enriched (TCE) populations were obtained by rosetting with amino-S-2 aminoethylisothiouronium bromide-treated sheep erythrocytes and passing the rosetted cells over Hypaque-Ficoll gradients (26). After lysis of the sheep erythrocytes, the final TCE population was obtained by passage over a nylon wool column (27). The rosettenegative cell population was used as the T cell-depleted (TCD) fraction. Monocyte depletion was accomplished by adherence to 4-mm Pyrex glass beads (Corning Glass Works, Corning Medical and Scientific Corning, NY) and passage through Sephadex G-10 (Pharmacia Fine Chemicals, Piscataway, NJ) (28). Monocyte-depleted cell fractions contained $<1$ nonspecific esterase-positive cell per 100 cells counted, unless otherwise stated (28). PBMCs irradiated with 2,000 rads were used as a source of monocytes.

Cell culture conditions. Cultures for the measurement of supernatant Ig production were performed in $1 \mathrm{ml}$ RPMI 1640 with $2 \mathrm{mM}$ glutamine, $10 \%$ fetal calf serum (FCS) (Gibco Laboratories, Gibco
Div., Grand Island, NY) with $10 \mu \mathrm{g} / \mathrm{ml}$ gentamicin in 24-well flat-bottomed plates with 16-mm wells (Costar, Data Packaging, Cambridge, MA).

The PBMCs were cultured at a density of $1.5 \times 10^{6}$ cells per 16 $\mathrm{mm}$ flat-bottomed well because this cell density and geometry has been shown to be optimal for antigen-induced, antigen-specific responses with a relative lack of polyclonal responses (15). Various cell fractions were cultured at different densities that had been determined to be optimal for the given fraction. The TCE fractions were cultured at 1 $\times 10^{6}$ cells per well and the TCD fractions at $0.5 \times 10^{6}$ cells per well, unless otherwise stated. Monocyte-depleted cell fractions were cultured at $0.75 \times 10^{6}$ cells per well, and the irradiated PBMCs used as a source of monocytes were cultured at a similar density. All add-back experiments were done with autologous cells. The $\mathrm{HBsAg}$ was diluted in RPMI and 10\% FCS and used at final concentrations of $1,0.1$, and $0.01 \mu \mathrm{g} / \mathrm{ml}$ protein. Tetanus toxoid (TT) antigen (Wyeth Laboratories, Marietta, PA) was also diluted in RPMI and $10 \%$ FCS and used at a final concentrations of 10 and $20 \mathrm{ng} / \mathrm{ml}$ protein. PWM (Gibco Laboratories, Gibco Div.) was used at a final concentration of 1:200. Cells were irradiated with a ${ }^{137}$ cesium source (Isomedix, Inc., Whippany, $\mathrm{NJ})$. The cultures were incubated in a $5 \% \mathrm{CO}_{2}$ atmosphere at $37^{\circ} \mathrm{C}$ and rocked at 4 cycles $/ \mathrm{min}$. After $12-14 \mathrm{~d}$ in culture the supernatants from 2 wells were combined into a single tube, spun at $700 \mathrm{~g}$ at room temperature for $5 \mathrm{~min}$, decanted, and stored at $4^{\circ} \mathrm{C}$ until evaluated, usually within 2 wk. Each experimental point was set up in 8 wells, resulting in quadruplicate samples for each point.

The mixed leukocyte reaction (MLR) supernatants were prepared by allogeneic coculture of $10^{6}$ TCE and $10^{6}$ TCD cells from a second donor in 10\% FCS in RPMI 1640 with $2 \mathrm{mM}$ glutamine at a final volume of $2 \mathrm{ml}$ in 15-mm plastic wells (Linbro Div., Flow Laboratories, Inc., New Haven, CT). The supernatants were harvested at $48 \mathrm{~h}$, aliquoted, and stored at $-20^{\circ} \mathrm{C}$ until used. The supernatants were used at a final concentrations of 10 and $20 \%$ of the culture volume.

Cultures for measuring routine blast transformation were performed, as previously described, in 96-well round-bottomed microtiter dishes (Linbro Chemical Co., Hamden, CT) containing $1 \times 10^{5}$ cells per well in $0.1 \mathrm{ml}$ RPMI with $15 \%$ human A serum (29). Various amounts of HBsAg or TT were diluted in RPMI with $15 \%$ human A serum and added to the cultures. PWM was used at a final concentration of 1:100. The cultures for measuring the effects of monocyte depletion and indomethacin (Sigma Chemical Co., St. Louis, MO) on blast transformation were performed in 96-well flat-bottomed plates cultured at 1 $\times 10^{5}$ cells per well. The indomethacin was dissolved in ethanol and used at final concentrations of 5 and $1 \mu \mathrm{g} / \mathrm{ml}$. The controls in these studies were cultured with an equivalent final concentration of ethanol. The cultures were incubated in $5 \% \mathrm{CO}_{2}$ at $37^{\circ} \mathrm{C}$ for $6 \mathrm{~d}$ unless otherwise stated.

Assays. Modifications of previously described enzyme-linked immunosorbent assays (ELISAs) $(14,15,30)$ were used to develop an ELISA to measure anti-HBs IgG in supernatant culture fluids. $\mathrm{HBsAg}$ at a final concentration of $0.5 \mu \mathrm{g} / \mathrm{ml}$ was mixed with $0.1 \mathrm{M}$ sodium carbonate coating buffer, $\mathrm{pH} 9.6$ at $4^{\circ} \mathrm{C}$, and $200 \mu \mathrm{l}$ of the solution was aliquoted into each well on a 96-well flat-bottomed microtiter plate (Immulon I; Dynatech Laboratories, Inc., Alexandria, VA), sealed occlusively with pressure-sensitive film (Falcon Labware, Div. of Becton, Dickinson \& Co., Oxnard, CA), and stored at $4^{\circ} \mathrm{C}$. The plates were usually prepared $24-48 \mathrm{~h}$ before being used. A 1:1000 dilution of goat $F\left(a b^{\prime}\right)_{2}$ fragment antihuman IgG ( $\gamma$-chain specific) alkaline phosphate conjugate (lot 62F8830; Sigma Chemical Co.) was made in a diluent buffer (0.05 M Tris- $\mathrm{HCl}$, pH 8.1, $1 \mathrm{mM} \mathrm{MgCl}_{2}, 0.15 \mathrm{M} \mathrm{NaCl}, 0.05 \%$ 
Tween-20, $0.02 \%$ sodium azide, $1 \%$ bovine serum albumin) as previously described (31). Before it was used, the plate coated with HBsAg was washed three times with $0.05 \%$ Tween-20 (Sigma Chemical Co.) in phosphate-buffered saline (PBS). Residual fluid was tapped from the wells between washes. After the final wash, residual fluid was aspirated by hand from each well with a polypropylene tip (Medical Laboratory Automation, Inc., Mount Vernon, NY) and attached to wall suction, and $200 \mu \mathrm{l}$ of standard or sample was rapidly placed into the appropriate well (each point was routinely done in triplicate). The plate was once again sealed with pressure-sensitive film and stored at $4^{\circ} \mathrm{C}$ for $4-6 \mathrm{~h}$. The plate was then washed three times as indicated above, and $200 \mu \mathrm{l}$ of the conjugate solution was rapidly placed into each well. The plate was again sealed with pressure-sensitive film and stored at $4^{\circ} \mathrm{C}$ for 18 $h$ (overnight). The plate was then washed five times in Tween-20 PBS, and fluid was aspirated from the individual wells, as noted above, after three of the washes, whereas residual fluid was only tapped from the wells after two washes. The washing procedure was carried out over $30-45 \mathrm{~min}$ to allow the plate to reach room temperature. Then, 200 $\mu \mathrm{l}$ of solution containing $p$-nitrophenylphosphate $(1 \mathrm{mg} / \mathrm{ml})$ (Sigma Chemical Co.) in carbonate buffer, $\mathrm{pH} 8.6$, with $0.001 \mathrm{M} \mathrm{MgCl}_{2}$ was added to each well, and the plate was sealed with pressure-sensitive film. The plate was then stored in the dark at room temperature and periodically evaluated for the development of color (usually 2-6 h). The outside wells were not used because of the higher backgrounds noted in these wells. The subsequent development of color was detected on a multichannel spectrophotometer (Dynatech Laboratories, Inc.) and compared with a standard prepared by dilution of human hepatitis B Ig (lot C5729A; Cutter Laboratories, Inc., Berkeley, CA) in 10\% FCS in RPMI. The spectrophotometer was blanked on a $10 \%$ FCS RPMI control before reading of the plate. A dilution of $10^{-7}$ was arbitrarily assigned a value of $1 \mathrm{U}$ of antibody to HBsAg. An ELISA to measure total supernatant IgG production was employed as previously described in detail $(14,15)$.

A commercially available radioimmunoassay to measure anti-HBs Ig (Ausab) was employed to measure the level of anti-HBs IgG in serum samples. The results were expressed as a ratio of counts per minute of the sample to the counts per minute of a standard negative control. The cut-off point for a negative serum sample was 2.1 times the mean value of the negative controls.

Blast transformation was measured in cultures set up as outlined above. Cultures were pulsed with $2 \mu \mathrm{Ci}$ of $\left[{ }^{3} \mathrm{H}\right]$ thymidine on day 6 and harvested $4 \mathrm{~h}$ later on a cell harvester (Titertek; Flow Laboratories, Inc., Rockville, MD). The filter disks were placed in scintillation vials with $3 \mathrm{ml}$ Aquasol scintillation fluid (New England Nuclear, Boston, MA) and counted in a scintillation counter (model LS-350; Beckman Instruments Inc., Fullerton, CA).

Statistics. The geometric means of the four replicate supernatants were determined for each individual. Data from multiple individuals are expressed as arithmetic means. Results were compared by a twotailed $t$ test.

\section{Results}

In vitro induction of anti-HBs IgG. The anti-HBs IgG and total IgG responses to in vitro stimulation with $\mathrm{HBsAg}$ and PWM in a temporal relationship to booster immunization are seen in Fig. 1. The mean serum anti-HBs serum titer after the first immunization, as measured in the Ausab radioimmunoassay, was $11.1 \pm 5.1$ in the six individuals studied in Fig. 1 as compared with $10.7 \pm 4.3$ for the remaining eight individuals $(P \gg 0.2)$. This observation suggests that there was no significant selection bias in studying these 6 individuals, compared with the total study group of 14 responders as a whole. Before immunization (Fig. $1 A$ ) no specific antibody was detected even in the cultures stimulated with the $T$ cell-dependent polyclonal B cell activator PWM $(P \gg 0.2)$. By 2 wk after immunization (Fig. $1 B$ ) there was marked spontaneous production of anti-HBs IgG culture, which could not be further enhanced by the presence of PWM or HBsAg $(P>0.2)$. There was a striking shift in the patterns of anti-HBs IgG production by 4 wk after immunization (Fig. $1 C$ ). Little spontaneously secreted anti-HBs IgG was detectable at this point $(P \gg 0.2)$. There was, however, a striking induction of anti-HBs IgG production by $\mathrm{HBsAg}(P<0.01)$. This antigen-induced antiHBs IgG response was not part of an overall polyclonal response because the total amounts of IgG in the unstimulated (control) and antigen-stimulated cultures were similar ( $P$ $\gg 0.2$ ). Thus, the in vitro stimulation of PBMCs with $\mathrm{HBsAg}$ after immunization with $\mathrm{HBs} \mathrm{Ag}$ vaccine resulted in an increase in specific IgG production as part of an oligoclonal response. By 8 wk after immunization the antigen-induced anti-HBs IgG response could no longer be demonstrated $(P \gg 0.2)$, despite the fact that PWM could stimulate cells to secrete HBsAg-specific IgG (Fig. 1 D). Note that three of five individuals tested 5 mo or more after the last booster immunization demonstrated an HBsAg-induced production of anti-HBs IgG (data not shown). In the single individual tested at all time points after both the second and third immunizations, the pattern of: $(a)$ increased spontaneous secretion of anti-HBs IgG at 2 wk; $(b)$ antigen-induced anti-HBs IgG response at 4 wk; and $(c)$ the absence of an antigen-induced response, despite the stimulation of anti-HBs IgG with PWM at 8 wk, was demonstrated after each booster immunization. Although stimulation with $0.1 \mu \mathrm{g} / \mathrm{ml} \mathrm{HBsAg}$ resulted in peak stimulation of anti-HBs IgG (Fig. $1 \mathrm{C}$ ), the induction of specific antibody could also be demonstrated for $1 \mu \mathrm{g} / \mathrm{ml}(26.4 \pm 8.45 \mathrm{U}$ of antiHBs IgG) and $0.01 \mu \mathrm{g} / \mathrm{ml} \mathrm{HBsAg}(33.7 \pm 11.5 \mathrm{U}$ of anti-HBs IgG). The use of even higher or lower concentrations of antigen did not usually result in the production of anti-HBs IgG. It should be emphasized that all available data are presented in this and subsequent figures. The large standard errors seen in the total IgG levels reflect in part the normal biologic variability seen in human in vitro antibody responses.

Cellular requirements. The induction of in vitro anti-HBs IgG was shown to be monocyte dependent (Fig. 2). In the absence of monocytes, the induction of specific antibody production by antigen or PWM could not be demonstrated $(P$ $<0.01)$. The induction of in vitro anti-HBs IgG by HBsAg also depends upon the presence of $\mathrm{T}$ lymphocytes (all $P$ $\leqq 0.04$ ) (Fig. 3). Neither B cells plus monocytes nor $T$ cells plus monocytes could be triggered by antigen alone to produce specific antibody $(P \gg 0.2)$. The presence of B cells, monocytes, $\mathrm{T}$ cells, and $\mathrm{HBsAg}$ were required to stimulate anti-HBs IgG 

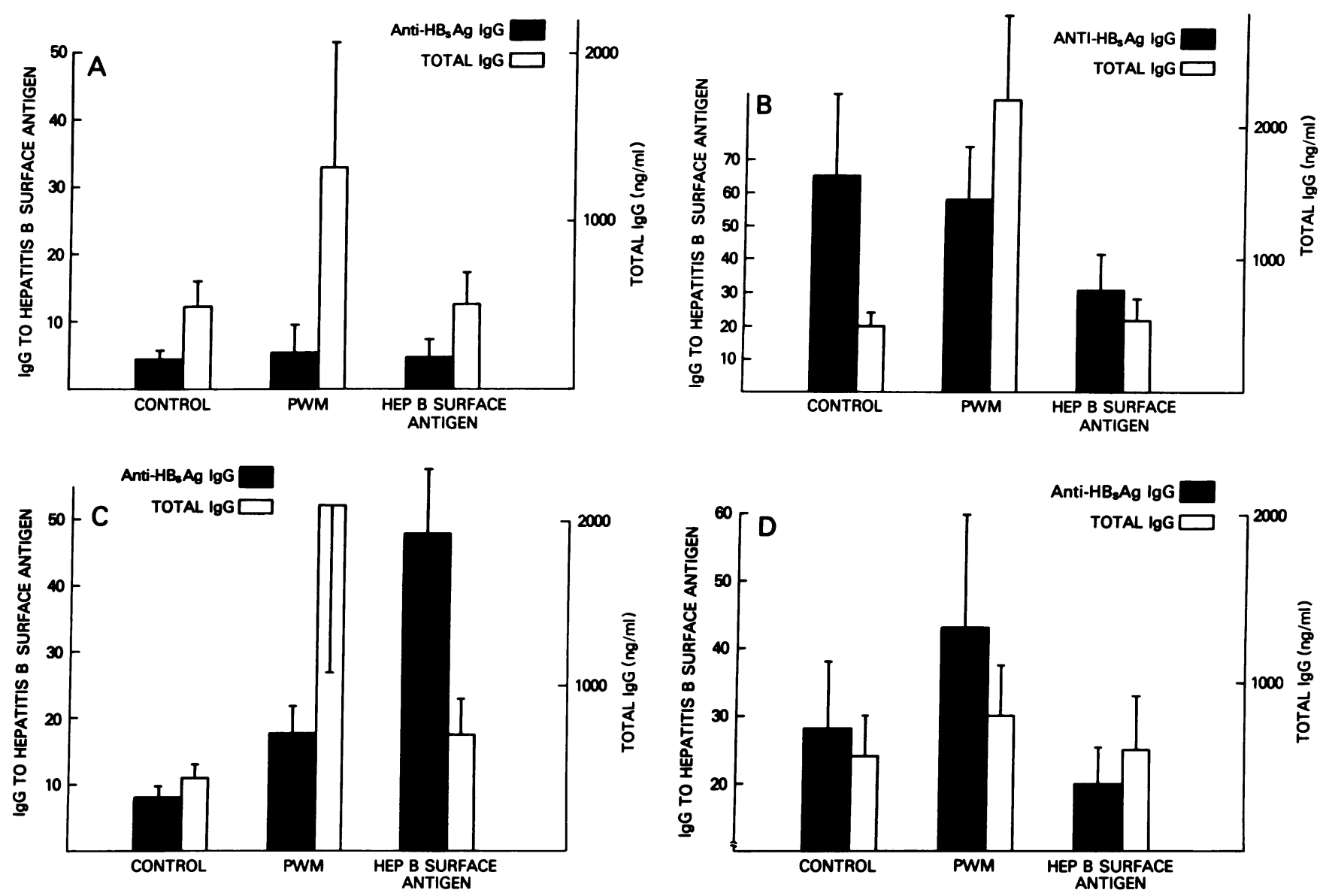

Figure 1. In vitro induction of anti-HBs IgG and total IgG after stimulation with $\mathrm{HBsAg}(0.1 \mu \mathrm{g} / \mathrm{ml})$ and PWM (1:200 dilution) various times after booster immunization. The data represent mean \pm SEM from $n$ individuals. $n$, Anti-HBs IgG in units of antibody

production. Similar cellular requirements for $\mathrm{T}$ cells, monocytes, and B cells were noted for PWM-stimulated anti-HBs IgG production (data not shown).

The irradiation sensitivity of the antigen-induced versus PWM-stimulated $T$ helper signals was evaluated next (Fig. 4). The TCE fractions were treated with different doses of irradiation. There was a striking dichotomy in the sensitivity of the $T$ helper cell signals to irradiation. At 2,000 rads there was marked potentiation of the PWM-stimulated response and substantial suppression of the antigen-induced response.

Induction of anti-HBs IgG production in the absence of HBsAg. An MLR supernatant was enough to induce the production of anti-HBs IgG in the absence of $T$ cells and antigen $(P<0.05)$ (Fig. 5). Furthermore, the addition of low concentrations of TT antigen to PBMC cultures of subjects recently immunized (within $1 \mathrm{yr}$ ) to TT as well as with $\mathrm{HBs} A g$ vaccine could stimulate anti-HBs IgG production (Fig. 6). Taken together, these observations suggest that the $B$ cells

to $\mathrm{HBsAg}$ (see Methods); $\square$, total IgG in nanograms per milliliter. $(A)$ Before immunization $(n=4)$. (B) 2 wk after booster immunization. (C) 3.5-4 wk after booster immunization $(n=6)$. (D) 6-8 wk after booster immunization $(n=6)$. HEP, hepatitis.

responsible for the specific antibody production are fairly advanced in the B cell activation/proliferation/differentiation sequence (32) and require only antigen nonspecific $T$ cell signals to induce specific antibody production. These signals can be delivered by a supernatant rich in nonspecific $T$ cell factors (MLR supernatant) or by the induction of secretion of $T$ cell factors by stimulating $T$ cells with a noncross-reacting antigen (in this case, TT) to which the individual is immune and to which one would expect a response by the activation of $T$ cells and the release of specific and nonspecific $T$ cell factors.

Blastogenic responses to $\mathrm{HBs} A \mathrm{~g}$. To characterize further the $\mathrm{T}$ cell immune response to $\mathrm{HBsAg}$, blastogenic responses to the antigen were evaluated. In other antigen-induced systems of specific antibody production that use keyhole limpet hemocyanin (KLH) as an antigen (15), a striking dichotomy between the lower doses of antigen that trigger optimal specific antibody production and the larger doses of antigen that 


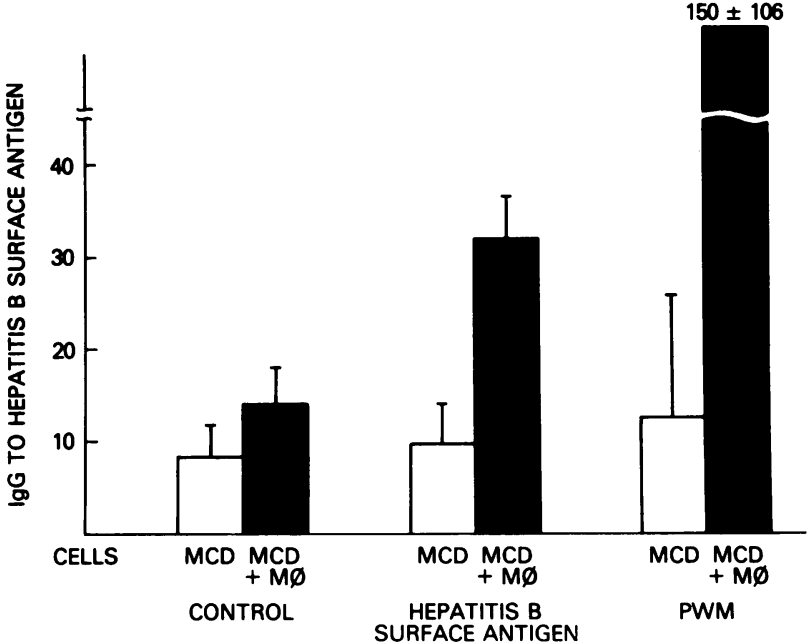

Figure 2. Monocyte dependence of HBsAg-induced, anti-HBs IgG responses $4 \mathrm{wk}$ after booster immunization. The data represent mean \pm SEM from three individuals. MCD, monocyte-depleted peripheral blood cell populations; $\mathbf{M} \phi$, unfractionated, autologous, irradiated PBMCs as a source of monocytes.

produce strong proliferative responses was demonstrated. In fact, the higher doses of $K L H$, which produce the optimal proliferative responses, profoundly suppress the antigen-induced antibody responses. In contrast to the KLH system, no proliferative responses to $\mathrm{HBsAg}$ could be clearly demonstrated across a broad range of concentrations $(P \gg 0.2)$ (Fig. 7). This lack of a demonstrable proliferative response to $\mathrm{HBsAg}$ was not due to a shift in the usual kinetics of the in vitro blastogenic response to antigens since no response was detectable across a broad time kinetic curve when it was compared with the kinetic curve seen with responses to stimulation with TT (Fig. 8). To exclude the possibility of low levels of

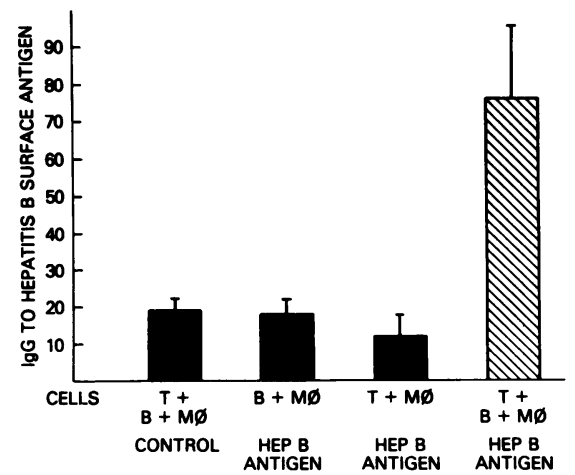

Figure 3. T cell dependence of HBsAg-induced anti-HBs IgG responses. The data represent mean \pm SEM of four individuals. $T$, $T$ cellenriched fractions; $B+M \phi$, T cell-depleted fractions; $M \phi$, irradiated, autologous PBMCs as a source of monocytes.

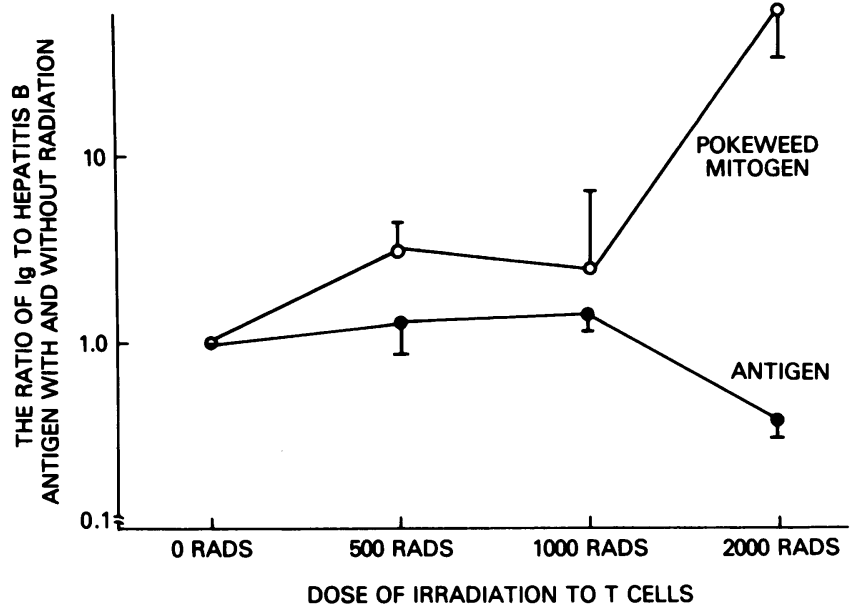

Figure 4. Effect of irradiation on the PWM-stimulated and antigentriggered $\mathrm{T}$ cell helper signals. The data from three individuals are expressed as geometric mean $(X / \div$ SEM) ratio of anti-HBs production in cultures with irradiated $T$ cells to the production in cultures with nonirradiated T cells for both PWM-stimulated (o) and antigenstimulated cultures $(\bullet)$. The $T$ cell-enriched populations were cultured at a density of $2 \times 10^{6}$ cells per well, and the T cell-depleted populations were cultured at a density of $0.5 \times 10^{6}$ cells per well.

antibodies to $\mathrm{HBsAg}$, proliferative responses were measured on day 6 in cultures with FCS. In five immunized individuals, the proliferative response was $9,336 \pm 1,808 \mathrm{cpm}$ in the presence of FCS alone and 8,429 $\pm 1,542 \mathrm{cpm}$ in the presence of $1 \mu \mathrm{g} /$ $\mathrm{ml} \mathrm{HBsAg}(P \gg 0.2)$. Again, no evidence of a proliferative

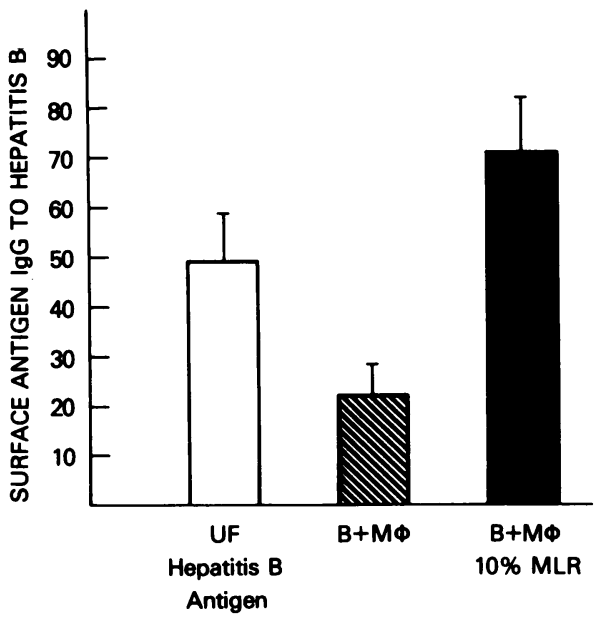

Figure 5. Mixed leukocyte reaction supernatants stimulate specific antibody production in the absence of $T$ cells and antigen. The data represent the mean \pm SEM from two individuals. UF, unfractionated PBMCs; B + M $\phi$, T cell-depleted fractions; MLR, mixed leukocyte reaction supernatants. The individuals were studied $4 \mathrm{wk}$ after booster immunization. 


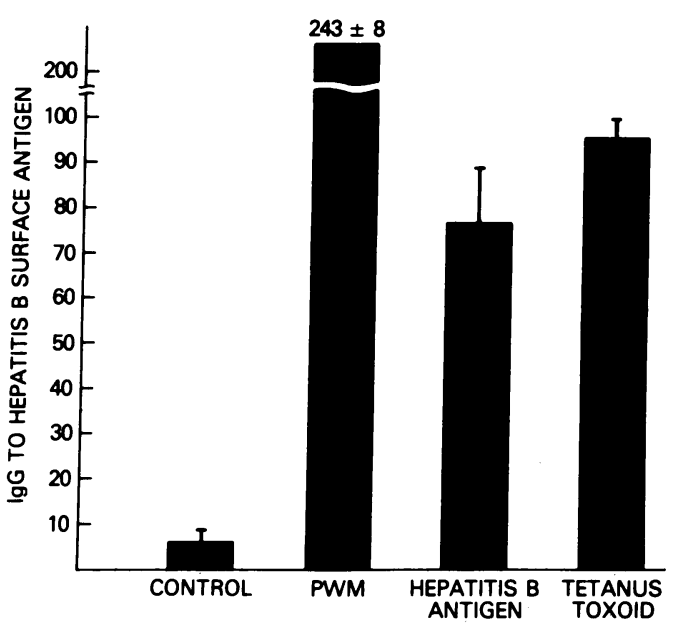

Figure 6. Induction of anti-HBs IgG production by stimulation of in vitro cultures with tetanus toxoid antigen in doubly immunized individuals. Data represent mean \pm SEM for two individuals. The HBsAg and TT antigen were used at final concentrations in culture of 100 and $20 \mathrm{ng} / \mathrm{ml}$, respectively.

response to $\mathrm{HBsAg}$ could be demonstrated. To evaluate the possibility of suppressor cell influences on the proliferative response to $\mathrm{HBsAg}$, blastogenic studies in partially adherent cell-depleted cell fractions (Table I) and in the presence of indomethacin (Table II) were performed. Neither partial adherence cell depletion nor the presence of indomethacin enhanced the proliferative response to $\mathrm{HBsAg}$. Finally, to exclude nonspecific suppressive and/or toxic responses, the effects of the addition of $\mathrm{HBsAg}$ on the proliferative response of PBMC to TT antigens were studied (Fig. 9). No inhibition of the proliferative response to TT was demonstrated after the addition of $\mathrm{HBsAg}$ to the cultures $(P \gg 0.2)$.

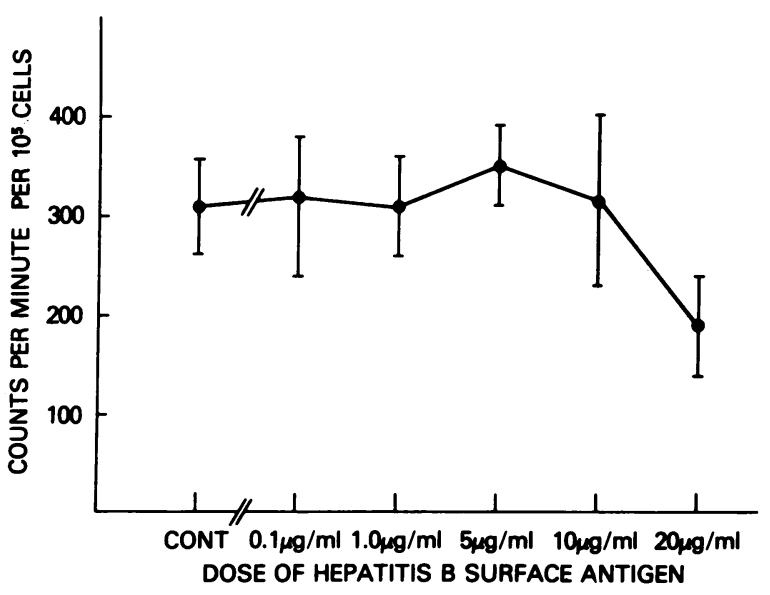

Figure 7. Absence of blastogenic responses to HBsAg. The data represent mean \pm SEM counts per minute per $1 \times 10^{5}$ cells harvested on day 6 from 14 individuals studied 1-8 wk after booster immunization.

\section{Discussion}

In the present study we have clearly demonstrated that after immunization with $\mathrm{HBsAg}$ vaccine it is possible to induce specific anti-HBsAg IgG responses by in vitro stimulation with low concentrations of HBsAg. The induction of specific antiHBs IgG responses is both $T$ cell and monocyte dependent and requires defined antigen concentration for an optimal response. Note that specific anti-HBs IgG in vitro responses are strikingly dependent on the time after booster immunization at which PBMCs are obtained. 2 wk after booster immunization there appear in the circulating lymphocyte pool B cells that are activated and that can spontaneously secrete anti-HBsAg IgG. Because these $B$ cells are already activated and far advanced along the differentiation pathways, as witnessed by the fact that they are spontaneously secreting antibody, additional stimulation with antigen or PWM does not further enhance, and in some cases suppresses, the response. By 4 wk after booster immunization there is a marked decline in spontaneous anti-HBs IgG production. However, the HBsAginduced production of anti-HBs IgG can be readily demonstrated at this point. Furthermore, stimulation with a polyclonal activator also results in an increased production of anti-HBs IgG, which is part of an overall increase in total IgG production.

The time point after booster immunization at which responses are measured is truly critical. In one individual studied 3 wk after booster, a pattern of increased spontaneous antiHBs IgG and an absence of the antigen-induced response was demonstrated. $4 \mathrm{~d}$ later, spontaneous antibody production was no longer detectable, and an antigen-induced, antigen-specific response was readily demonstrated. Note that the peak in vivo kinetic response for the antigen-induced, anti-HBs IgG response occurred later than the in vivo peak response reported in the KLH system, which was 2 wk after booster immunization (15). Differences in the antigen employed, immunization protocol, isotype of Ig measured, and dose of antigen used for immunization could explain this discrepancy between the two systems. By 8 wk after immunization, HBsAg-induced antiHBs IgG could no longer be demonstrated despite the presence of $B$ cells in the peripheral blood compartment that could be polyclonally activated by PWM to secrete anti-HBs IgG. The reason for the absence of the antigen-induced specific response at this kinetic point has not been clearly defined. Whether there is an absence of the appropriate $T$ cell or $B$ cell population in the peripheral blood compartment remains to be determined. The absence of $B$ cells in the peripheral blood compartment that can respond to specific antigenic signals has been suggested as a possible cause for unresponsiveness in one antigen-driven system (33). Alternatively, preliminary evidence in our laboratory in the $\mathrm{KLH}$ antigen-induced system suggests that the absence of antigen-responsive $T$ cells from the peripheral blood compartment may be responsible for the absence of antigen-induced specific Ig production (Lane, H. C., and A. S. Fauci, unpublished observations). Finally, after 5 mo or more, HBsAg-induced anti-HBs IgG can be demonstrated in 


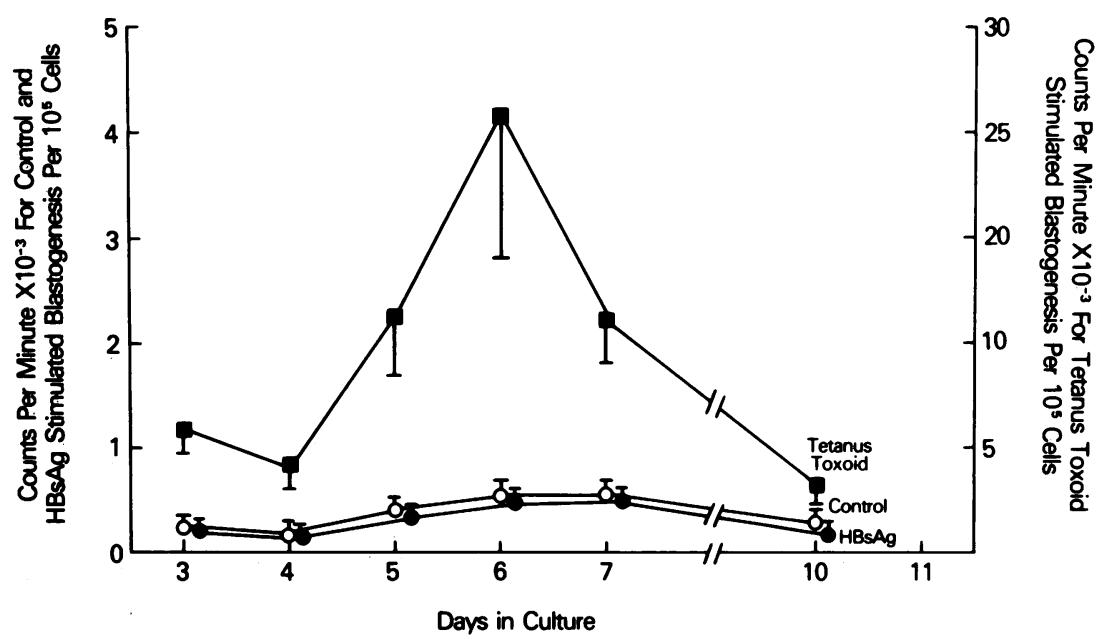

Figure 8. Kinetics of the blastogenic responses to HBsAg. Data represent the mean \pm SEM from six individuals. $\circ$, control cultures; $\bullet, \mathrm{HBsAg}$ at 1.0 $\mu \mathrm{g} / \mathrm{ml} ; \mathrm{n}$, TT at $5 \mu \mathrm{g} / \mathrm{ml}$ final concentration. some previously immunized individuals. This observation is in concordance with the ability to stimulate antigen-induced specific antibody responses to $\mathrm{KLH} \sim 1 \mathrm{yr}$ after immunization after a long refractory period (34). Thus, these observations provide new insights into the kinetic nature of the human immune response to $\mathrm{HBsAg}$, as reflected in the peripheral blood compartment.

After in vivo immunization, the in vitro induction of antiHBs IgG by specific antigen requires the presence of monocytes, $B$ cells, and T cells. The peripheral blood B cells involved in antigen-induced specific antibody responses appear to be fairly advanced in the B cell activation/differentiation sequence. In

Table I. Effect of Monocyte Depletion on Proliferative Responses to $\mathrm{HBSAg}$

\begin{tabular}{|c|c|c|c|c|}
\hline \multirow[b]{2}{*}{ Experiment } & \multirow[b]{2}{*}{ Cells } & \multicolumn{3}{|c|}{ Proliferation (cpm) } \\
\hline & & Unstimulated & HBsAg* & TT $\ddagger$ \\
\hline \multirow[t]{2}{*}{1} & Mononuclear cells & 490 & 529 & 88,756 \\
\hline & M $\phi$ depleted cells§ & 407 & 231 & 34,450 \\
\hline \multirow[t]{2}{*}{2} & Mononuclear cells & 164 & 257 & 29,094 \\
\hline & M $\phi$ depleted cells & 102 & 146 & 18,013 \\
\hline \multirow[t]{2}{*}{3} & Mononuclear cells & 158 & 248 & 27,036 \\
\hline & M $\phi$ depleted cells§ & 84 & 168 & 1,068 \\
\hline \multirow[t]{2}{*}{4} & Mononuclear cells & 134 & 205 & 76,249 \\
\hline & M $\phi$ depleted cells§ & 188 & 175 & - \\
\hline
\end{tabular}

Data expressed as counts per minute per $10^{5}$ cultured cells after $6 \mathrm{~d}$ in culture. $\mathbf{M} \phi$, unfractionated, autologous, irradiated PBMCs as a source of monocytes.

$* 5 \mu \mathrm{g} / \mathrm{ml}$, final concentration.

$\ddagger 10 \mu \mathrm{g} / \mathrm{ml}$, final concentration.

$\S$ Partially adherent cell-depleted population with 1:100, 1:300, 1:25, and 1:20 nonspecific esterase-positive cells for experiments 1 through 4 , respectively. the absence of $T$ cells and $\mathrm{HBsAg}$, anti-HBs $\operatorname{IgG}$ can be stimulated by nonspecific $T$ cell signals (MLR supernatants). Also, anti-HBs IgG can be stimulated by another antigen (i.e., TT) in the presence of TT-responsive $T$ cells in a doubly immunized individual. Presumably, interaction of the second antigen with a TT-responsive $T$ cell produces nonantigenrestricted $\mathrm{T}$ cell signals able to stimulate anti-HBs IgG production by $B$ cells that are already in the preactivated state after in vivo immunization. Similar findings have been reported in antigen-specific antibody systems for KLH, TT, and diphtheria antigen $(15,35)$, suggesting that antigen-specific activation of the appropriate B cell repertoire has occurred in vivo during the immunization sequence.

The HBsAg induction of anti-HBs IgG responses requires the presence of $T$ lymphocytes. The irradiation sensitivity of

Table II. Effect of Indomethacin on Proliferative Responses to $\mathrm{HBsAg}$

\begin{tabular}{|c|c|c|c|c|}
\hline \multirow[b]{2}{*}{ Experiment } & \multirow[b]{2}{*}{ Indomethacin* } & \multicolumn{3}{|c|}{ Proliferation $(c p m)$} \\
\hline & & Unstimulated & HBsAgf & TT§ \\
\hline \multirow[t]{2}{*}{1} & - & 160 & 361 & 60,922 \\
\hline & + & 244 & 318 & 46,522 \\
\hline \multirow[t]{2}{*}{2} & - & 267 & 120 & 19,228 \\
\hline & + & 161 & 98 & 19,973 \\
\hline \multirow[t]{2}{*}{3} & - & 188 & 219 & 10,470 \\
\hline & + & 132 & 142 & 5,501 \\
\hline \multirow[t]{2}{*}{4} & - & 119 & 117 & 76,249 \\
\hline & + & 118 & 141 & 85,673 \\
\hline
\end{tabular}

Data are expressed as counts per minute per $10^{5}$ cultured cells after $6 \mathrm{~d}$ in culture.

* Final concentration, $5 \mu \mathrm{g} / \mathrm{ml}$.

‡ Final concentration, $5 \mu \mathrm{g} / \mathrm{ml}$.

$\S$ Final concentration, $10 \mu \mathrm{g} / \mathrm{ml}$. 


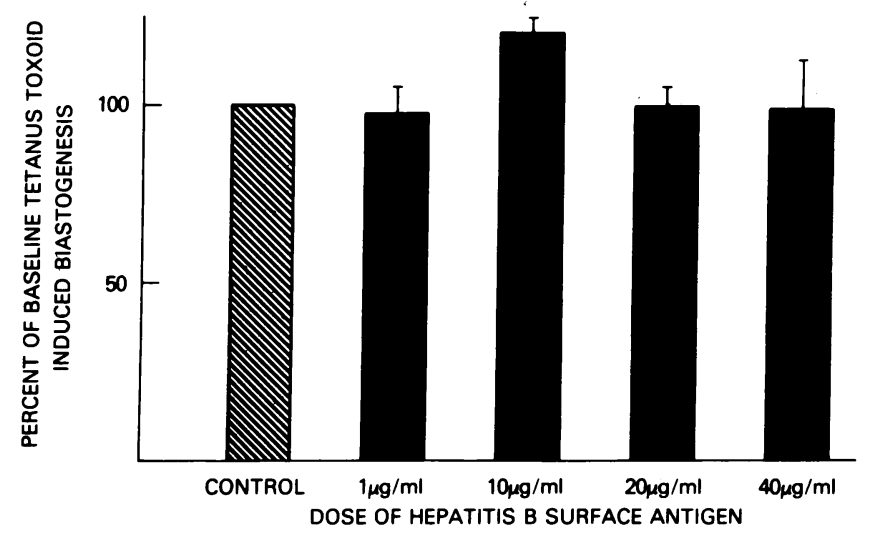

Figure 9. Absence of suppression of proliferative responses to TT antigen by the addition of varying doses of $\mathrm{HBsAg}$ to the culture. Data represent the mean \pm SEM of the baseline proliferative response to TT alone in three individuals.

the $T$ cell signals for anti-HBs IgG production after stimulation with the polyclonal activator PWM versus $\mathrm{HBsAg}$ is strikingly dissimilar (Fig. 4). When $\mathrm{T}$ cells were irradiated (2,000 rads), the production of specific IgG after stimulation with PWM increased substantially; in sharp contrast, anti-HBs IgG production after stimulation with antigen declined significantly. The relatively greater sensitivity to the effects of irradiation of the net $\mathrm{T}$ cell helper signal (the balance between helper and suppressor signals) in the antigen-induced system, when compared with the PWM-induced system, is similar to the pattern reported in other in vitro antigen-induced antibody systems $(15-17,19,36)$.

The $T$ cell immune response was further evaluated by the measurement of proliferative responses to $\mathrm{HBsAg}$ in immunized individuals. In the $\mathrm{KLH}$ antigen-induced system, we have reported a clear-cut dichotomy between the lower doses of antigen, that produce optimal in vitro $\mathrm{KLH}$-specific Ig production and the higher doses of antigen that produce excellent proliferative responses but suppress specific antibody production (15). In contrast to readily demonstrated proliferative responses to soluble protein antigens such as KLH and TT (15) or viral antigen such as influenza (37) or varicella zoster (38) in a suitably immunized individual, no detectable proliferative response to $\mathrm{HBsAg}$ was demonstrated, despite evidence of a substantial serologic immune response in 14 immunized individuals. Regardless of the presence of specific $T$ cell immunity to $\mathrm{HBsAg}$ demonstrated by the $\mathrm{T}$ cell dependence of induction of anti-HBs IgG production, no evidence of $\mathrm{T}$ cell immunity as reflected in a blastogenic response could be demonstrated. This dichotomy of the $T$ cell immune responses ( $T$ cell requirement for antigen-induced specific $\mathrm{Ig}$ production in the face of an absent proliferative response to $\mathrm{HBsAg}$ ) appears to be a unique feature of the human immune response to $\mathrm{HBsAg}$.

The explanation for the nondetectable proliferative response to $\mathrm{HBsAg}$ despite the presence of well-established humoral immunity has not been clearly defined. The absent proliferative response was not the result of a shift in the dose-response or kinetic curves. Although nonspecific suppression of proliferative responses by viral particles has been reported $(39,40)$, no nonspecific suppressive or toxic effects of $\mathrm{HBsAg}$ could be demonstrated on the proliferative responses to TT antigen. The presence of adherent and/or prostaglandin-producing suppressor cells able to decrease proliferative responses has been described in a number of disease states, including Hodgkin's disease (41) and chronic infections (42-44). Despite adherent cell depletion or the use of a prostaglandin inhibitor (indomethacin), no reconstitution of a proliferative response to HBsAg could be demonstrated. However, these studies do not exclude the possibility of antigen-specific suppressor $T$ cell populations. Recent studies by Peterson et al. (45) which examined the immune response to amino acid peptide sequences in the mouse suggest that the $T$ cells that provide help for specific Ig production and $\mathrm{T}$ cells that proliferating to antigen stimulation may be functionally distinct subsets of cells and that responsiveness in one subpopulation did not predict the response pattern of other functional subpopulations. The findings in the present study are compatible with the hypothesis that different functional subsets of $\mathrm{T}$ cells are responsible for proliferative responses and helper cell function for Ig production to $\mathrm{HBsAg}$.

The human immune response, including cellular immune reactivity to $\mathrm{HBsAg}$, has been extensively evaluated by a variety of techniques, including migration inhibition, cytotoxicity assays, and blast transformation after infection with hepatitis B virus (reviewed, 9 and 10). In the convalescent phase after resolution of hepatitis B viral infection, blastogeneic responses to HBsAg have been reported by some (46-48) but not all authors (49). In the papers that report positive results, the stimulation index has been relatively low (usually $\leqq 5$ ). The reasons for the disparate results are unclear, but technical differences in studies, including the serum source used for culture, the source, dose, and purity of $\mathrm{HBsAg}$, as well as other experimental parameters, may be relevant. In this regard, the description of a serum protein in the blood of some patients with hepatitis $B$ viral infection that can modulate $T$ lymphocyte receptors $(50,51)$ and the description of an albumin receptor on $\mathrm{HBsAg}(52,53)$ clearly emphasize the unique and complex nature of the interaction between hepatitis $B$ virus and the human host.

In this report, we have demonstrated the ability to evaluate antigen-specific immune response to $\mathrm{HBsAg}$ at the $\mathrm{B}$ cell and $T$ cell level. The studies reported here provide a model system to examine the complexities of the immune response to HBsAg and may prove useful in dissecting out the aberrations of the immune response to this clinically relevant antigen which may be involved in immune-mediated diseases associated with hepatitis $B$ virus infection (1-6).

\section{Acknowledgments}

The expert editorial skills of Ms. Ann C. London and Ms. Betty Sylvester are greatly appreciated. The authors wish to thank Drs. David 
J. Volkman and H. Clifford Lane for their productive discussions and review of the manuscript.

\section{References}

1. Hoofnagle, J. H. 1981. Type B hepatitis. Serology, virology, and clinical course. Semin. Liver Dis. 1:6-13.

2. Levo, Y., P. D. Gorevic, H. J. Kassab, D. Zucker-Franklin, and E. C. Franklin. 1977. Association between hepatitis B virus and essential mixed cryoglobulinemia. $N$. Engl. J. Med. 296:1501-1504.

3. Brzosko, W. J., K. Krawczynski, T. Nazarewicz, M. Morzycka, and A. Nowoslawski. 1974. Glomerulonephritis associated with hepatitisB surface antigen immune complexes in children. Lancet. 2:477-482.

4. Kohler, P. F., R. E. Cronin, W. S. Hammond, D. Olin, and R. I. Carr. 1974. Chronic membranous glomerulonephritis caused by hepatitis B antigen-antibody immune complexes. Ann. Intern. Med. $81: 448-451$.

5. Sergent, J. S., M. D. Lockshin, C. L. Christian, and D. J. Gocke. 1976. Vasculitis with hepatitis B antigenemia. Long-term observations in nine patients. Medicine (Baltimore). 55:1-18.

6. Duffy, J., M. D. Lidsky, J. T. Sharp, J. S. Davis, D. A. Person, F. B. Hollinger, and K. W. Min. 1976. Polyarthritis, polyarteritis and hepatitis B. Medicine (Baltimore). 55:19-37.

7. Sherlock, S., R. A. Fox, S. P. Niazi, and P. J. Scheuer. 1970. Chronic liver disease and primary liver-cell cancer with hepatitisassociated (Australia) antigen in serum. Lancet. 1:1243-1247.

8. Bolin, T. D., A. E. Davis, and A. G. Liddelow. 1973. Liver disease and cell-mediated immunity in hepatitis-associated antigen (HAA) carriers. Gut. 14:365-368.

9. Bianchi, L., and F. Gudat. 1979. Immunopathology of hepatitis B. In Progress in Liver Diseases. H. Popper and F. Schaffner, editors. Grune and Stratton, Inc., New York. 6:371-392.

10. Meyer zum Büschenfelde, K. H., T. H. Hütteroth, W. Arnold, and V. Hopf. 1979. Immunologic liver injury: the role of hepatitis $B$ viral antigens and liver membrane antigens as targets. In Progress in Liver Diseases. H. Popper and F. Schaffner, editors. Grune \& Stratton, Inc., New York. 6:407-424.

11. Fauci, A. S., and R. E. Ballieux, editors. 1979. Antibody Production in Man. In Vitro Synthesis and Clinical Implications. Academic Press Inc., New York.

12. Möller, G. 1979. Activation of Antibody Synthesis in Human B Lymphocytes. Transplant. Rev. 45.

13. Dusheiko, G. M., J. H. Hoofnagle, W. G. Cooksley, S. P. James, and E. A. Jones. 1983. Synthesis of antibodies to hepatitis virus by cultured lymphocytes from chronic hepatitis B surface antigen carriers. J. Clin. Invest. 71:1104-1113.

14. Volkman, D. J., H. C. Lane, and A. S. Fauci. 1981. Antigeninduced in vitro antibody production by humans: a model for B cell activation and immunoregulation. Proc. Natl. Acad. Sci. USA. 78:25282531.

15. Lane, H. C., D. J. Volkman, and A. S. Fauci. 1981. In vitro antigen-induced, antigen specific antibody production in man. Specific and polyclonal components, kinetics, and cellular requirements. $J$. Exp. Med. 154:1043-1057.

16. Volkman, D. J., S. P. Allyn, and A. S. Fauci. 1982. Antigeninduced in vitro antibody production in humans: tetanus toxoidspecific antibody synthesis. J. Immunol. 129:107-112.

17. Callard, R. E. 1979. Specific in vitro antibody response to influenza virus by human blood lymphocytes. Nature (Lond.). 282:734 736.

18. Souhami, R. L., J. Babbage, and R. E. Gallard. 1981. Specific in vitro antibody response to varicella zoster. Clin. Exp. Immunol. 46:98-105.

19. Yarchoan, R., B. R. Murphy, W. Strober, H. S. Schneider, and D. L. Nelson. 1981. Specific anti-influenza virus antibody production in vitro by human peripheral blood mononuclear cells. J. Immunol. 127:2588-2594.

20. Szmuness, W., C. E. Stevens, E. J. Harley, E. A. Zang, W. R. Oleszko, H. J. Alter, P. E. Taylor, A. DeVera, G. T. S. Chen, A. Kellner, and the Dialysis Vaccine Trial Study Group. 1980. Hepatitis B vaccine. Demonstration of efficacy in a controlled clinical trial in a high-risk population in the United States. N. Engl. J. Med. 303:834841.

21. McAuliffe, V. J., R. H. Purcell, J. L. Gerin, and F. J. Tyeryar 1982. Current status of NIAID hepatitis B vaccines. In Viral Hepatitis 1981. International Symposium. W. Szmuness, H. Alter, and J. Maynard, editors. The Franklin Institute Press, Philadelphia. 425-435.

22. Francis, D. P., S. C. Hadler, S. E. Thompson, J. E. Maynard, D. G. Ostrow, N. Altman, E. H. Braff, P. O'Malley, D. Hawkins, F. N. Judson, K. Penley, T. Nylund, G. Christie, F. Meyers, J. N. Moore, Jr., A. Gardner, I. L. Doto, J. H. Miller, G. H. Reynolds, B. L. Murphy, C. A. Schable, B. T. Clark, J. W. Curran, and A. G. Redeker. 1982. The prevention of hepatitis B with vaccine. Report of the Centers for Disease Control multi-center efficacy trial among homosexual men. Ann. Intern. Med. 97:362-366.

23. Gerin, J. L., R. M. Faust, and P. V. Holland. 1975. Biophysical characterization of the adr subtype of hepatitis $B$ antigen and preparation of anti-r sera in rabbits. J. Immunol. 115:100-105.

24. Lowry, O. H., N. J. Rosenbrough, A. L. Farr, and R. J. Randall. 1951. Protein measurement with folin phenol reagent. J. Biol. Chem. 193:265-275.

25. Boyum, A. 1968. Isolation of mononuclear cells and granulocytes from human blood. Scand. J. Clin. Invest. 21(Suppl.):77-89.

26. Falkoff, R. J. M., L. P. Zhu, and A. S. Fauci. 1982. Separate signals for human B cell proliferation and differentiation in response to Staphylococcus aureus. Evidence for a two signal model of B cell activation. J. Immunol. 129:97-102.

27. Werner, C. H., P. T. Klouda, M. C. Correa, P. Vassali, and M. Jeannet. 1977. Isolation of $B$ and $T$ lymphocytes by nylon fiber columns. Tissue Antigens. 9:227-229.

28. Gerrard, T. L., and A. S. Fauci. 1982. Activation and immunoregulation of antigen specific human B lymphocyte responses. Multifaceted role of the monocyte. J. Immunol. 128:2367-2372.

29. Fauci, A. S., and D. C. Dale. 1975. Alternate-day prednisone therapy and human lymphocyte subpopulations. J. Clin. Invest. 55:2232.

30. Engvall, E., and P. Perlmann. 1972. Enzyme-linked immunosorbant assay, ELISA. III. Quiantification of specific antibodies by enzyme-labeled anti-immunoglobulin in antigen coated plates. $J$. Immunol. 109:129-135.

31. Goldsmith, P. K. 1981. A highly-sensitive enzyme-linked immunosorbent assay for human IgE: comparison of microtiter plate and disk methodologies. Anal. Biochem. 117:53-60.

32. Muraguchi, A., J. L. Butler, J. H. Kehrl, and A. S. Fauci. 1983. Differential sensitivity of B cell subsets to activation signals delivered by anti- $\mu$ antibody and proliferative signals delivered by a monoclonal B cell growth factor. J. Exp. Med. 157:530-546.

33. Callard, R. E., G. W. McCaughan, J. Babbage, and R. L. Souhami. 1982. Specific in vitro antibody responses by human blood lymphocytes: apparent nonresponsiveness of PBL is due to a lack of recirculating memory B cells. J. Immunol. 129:153-156.

34. Lane, H. C., L. C. Edgar, G. Whalen, and A. S. Fauci. 1983. 
Kinetics of the sequential presence in human peripheral blood of antigen-specific activated, inducible memory B lymphocytes. Fed. Proc. 42:411.

35. Peters, M., and A. S. Fauci. 1983. Selective activation of antigen-specific human $B$ cells in recently immunized individuals by nonspecific factors in the absence of antigen. J. Immunol. 130:678680.

36. Lane, H. C., G. Whalen, and A. S. Fauci. 1983. Antigeninduced human $\mathrm{T}$ cell help: precursor frequency, radiation sensitivity, and allogenic effects. J. Clin. Invest. 72:636-647.

37. Dolin, R., B. R. Murphy, and E. A. Capkin. 1978. Lymphocyte blastogenic responses to influenza virus antigens after influenza infection and vaccination in humans. Infect. Immun. 19:867-874.

38. Arvin, A. M., R. B. Pollard, L. E. Rasmussen, and T. C. Merigan. 1978. Selective impairment of lymphocyte reactivity to varicella-zoster virus antigen among untreated patients with lymphoma. J. Infect. Dis. 137:531-540.

39. Lucas, C. J., J. M. D. Galama, and J. Ubels-Postma. 1977. Measles virus-induced suppression of lymphocyte reactivity in vitro. Cell. Immunol. 32:70-85.

40. Wainberg, M. A., and E. Israel. 1980. Viral inhibition of lymphocyte mitogenesis. I. Evidence for nonspecificity of the effect. $J$. Immunol. 124:64-70.

41. Goodwin, J. S., R. P. Messner, A. D. Bankhurst, G. T. Peake, J. H. Saiki, and R. C. Williams. 1977. Prostaglandin-producing suppressor cells in Hodgkin's disease. $N$. Engl. J. Med. 297:963-968.

42. Ellner, J. J. 1978. Suppressor adherent cells in human tuberculosis. J. Immunol. 121:2573-2579.

43. Ottesen, E. A. 1979. Modulation of host response in human schistosomiasis. I. Adherent suppressor cells that inhibit lymphocyte proliferative responses to parasite antigens. J. Immunol. 123:16391644
44. Piessens, W. F., S. Ratiwayanto, S. Tuti, J. H. Palmieri, P. W. Piessens, I. Koiman, and D. T. Dennis. 1980. Antigen-specific suppressor cells and suppressor factors in human filariasis with Brugia malayi. $N$. Engl. J. Med. 302:833-837.

45. Peterson, L. B., G. D. Wilner, and D. W. Thomas. 1983. Proliferating and helper $\mathrm{T}$ lymphocytes display distinct specificities in response to human fibrinopeptide B. J. Immunol. 130:2542-2545.

46. Laiwah, A. C. C. Y., A. K. R. Chaudhuri, and J. R. Anderson. 1973. Lymphocyte transformation and leukocyte migration inhibition by Australia antigen. Clin. Exp. Immunol. 15:27-34.

47. DeGast, G. L., B. Houwen, and H. O. Niewig. 1973. Specific lymphocyte stimulation by purified, heat-inactivated hepatitis B antigen. Br. Med. J. 4:707-709.

48. Tong, M. J., A. M. Wallace, R. L. Peters, and T. B. Reynolds. 1975. Lymphocyte stimulation in hepatitis B infection. N. Engl. J. Med. 293:318-322.

49. Wands, J. R., J. L. Perrotto, E. Alperti, and K. J. Isselbacher. 1975. Cell-mediated immunity in acute and chronic hepatitis. J. Clin. Invest. 55:921-929.

50. Chisari, F. V., and T. S. Edgington. 1975. Lymphocyte E rosette inhibitory factor: a regulatory serum lipoprotein. J. Exp. Med. 142:1092-1107.

51. Chisari, F. V., J. A. Routenberg, and T. S. Edgington. 1976. Mechanisms responsible for defective human T-lymphocyte sheep erythrocyte rosette function associated with hepatitis B virus infection J. Clin. Invest. 57:1227-1238.

52. Neurath, A. R., and N. Strick. 1979. Radioimmunoassay for albumin-binding sites associated with HBsAg: correlation of results with the presence of e-antigen in serum. Intervirology. 11:128-132.

53. Imai, M., Y. Yanase, T. Nojiri, Y. Migakawa, and M. Mayumi. 1979. A receptor for polymerized human and chimpanzee albumins in hepatitis B virus particles co-occurring with $\mathrm{HBsAg}$. Gastroenterology. 76:242-247. 